Denisa Krbec ${ }^{1}$

David M. Currie ${ }^{2}$

UDK 378.633-057.87:159.953.5>371.388

Review

Pregledni rad

\title{
ADVANTAGES OF EXPERIENTIAL LEARNING IN DEVELOPMENT OF INTERNATIONAL ECONOMICS AND BUSINESS STUDY PROGRAMS ${ }^{3}$
}

\begin{abstract}
The processes of internationalization especially in higher education should respect the uniqueness of individual societies and culture, and - in the face of the forces of globalization - should also urge understanding and cooperation at academic level. In this context, the international dimension can be elaborated as a perspective, activity or program which integrates an intercultural outlook into the major functions of a university.

The Global Business Practicum at Rollins and the collaboration between Rollins College and University of Pula provide numerous illustrations of what can be learned about international business by students participating in work-directed projects, and how projects of international cooperation can be evaluated both according to the ECTS and USA grading system's requirements.
\end{abstract}

Keywords: experiential learning, students' experience, economics\&business education, practicum, Croatia

\section{INTRODUCTION}

Among basic features of the Bologna process the introduction of a structure that facilitates comparability with the other higher education systems is certainly an important one. In terms of internationalization, several researches' results stressed that the Bologna process forces the European HE institutions to restructure their degrees even they are moving at different speed which is not always easy to follow mainly for non-European's partners (e.g. Charon Wauters, 2006; Currie, Krbec \& Higgins, 2005; Matulich, 2003). Based largely on research cooperation and its productivity, diverse forms of existing tools could be appropriately introduce as matrix in which opportunities, exploration, differentiation and ranking/grading can occur. In addition, current developments in quality assurance may provide nearly simultaneous mechanisms for the comparison of teaching and learning outcomes alongside research outputs (ESF, 2008:17).

Trying to find the best model of an international recognition in higher education accross the world, institutions are encouraged to develop and pursue their own distinct internationalization profiles. Based on choices that fit their strengths, particular

\footnotetext{
${ }^{1}$ Professor, Juraj Dobrila University of Pula, Department of Economics and Tourism „Dr. Mijo Mirković“: denisa.krbec@unipu.hr

${ }^{2}$ Professor, Rollins College, Crummer Graduate School of Business, Winter Park, FL, USA: dcurrie@rollins.edu

${ }^{3}$ This paper contains some research results of international cooperation in the field of tourism higher education and educational competencies, which are the subject of scientific research on „Sustainable Tourism in Croatia: A Taste of Istria“ (Project No. 303-0000000-2451, MSES RH). Auhors are particulary gratefull to participants of the International Conference on ,Internationalisation and the Role of University Networks“, held from September 25-26, 2009 in Portorož, Slovenia for their discussion.
} 
characteristics, environment and their own steering models, they often extend theoretical approaches and forced practices that improve the quality of higher education internationally. Among many practices of educational development, experiential learning enhance the learning experiences. The learning outcomes from an international business practicum additionally complement the traditional class setting and give the students perspectives which are difficult to bring into the classroom.

Since the academic year 1999/2000, the Faculty of Economics and Tourism (FET) in Pula, Croatia (now the Department of Economics and Tourism, Juraj Dobrila University of Pula; further: OET UniPu) has actively participated in a global practicum in which students from FET collaborate with students from the Crummer Graduate School of Business of Rollins College, Winter Park, Florida, USA. The practicum "Collaborative Student and Faculty Experiential Exchanges" is partially supported by a grant from the Fulbright Foundation and co-financed by Ministry of Science, Education and Sport Republic of Croatia.

The program consists of two parts: 1) students and faculty from Rollins College travel to Pula to conduct a global business practicum for Istria County, and 2) students and faculty from UniPu travel to Winter Park to study and observe tourism. Winter Park is adjacent to Orlando, one of the world's major tourist attractions and the site of numerous theme parks.

The Global Business Practicum at Rollins (further: GBP) and the collaboration between Rollins and University of Pula provide numerous illustrations of what can be learned about international business by students participating in work-directed projects. Following the World Conference on Higher Education's (1997) statement about the unequal distribution of high level training and research, the practicum was based on a firm academic foundation at both institutions from its beginning in 2000. After completing the first ten years of both academic and professional experiences of this unique program's collaboration, it's confirmed that this form of collaborative activity provides insight into the problems facing the Croatian academic community as it attempts to modernize the system of higher education and to innovate teaching and learning experiences as well.

This paper aim is to elaborate current practices of this unique international university cooperation based on a true internationally-based program. The paper is divided into four parts. After presenting the theoretical basis underlying development of international collaborations in Part 2, Part 3 focuses on the internationalization of business education. Part 4 analyses development of the Global Business Practicum (GBP) as an international cooperation's program, and elaborates the GBP as an innovative international collaboration from a Croatian perspective. We also suggested a complex method of evaluating collaborations such as the Global Business Practicum taking into the consideration sides involved in - students, faculty, institution and government. Before concluding remarks, we propose several highlights to be discussed in a near future. 


\section{THEORETICAL BASIS FOR THE GLOBAL BUSINESS PRACTICUM}

The Bologna process forces the European HE institutions to restructure their degrees but the institutions are doing so at different speeds, which is not always easy to follow mainly for non-European's partners. While the current practices are based mainly on access to programs offered by well-known universities, a true internationally-based program is much more adapted to local conditions and needs. These practices include the following reflection questions:

1. What are the models of international university cooperation?

2. Is the "collaborative learning" strategy useful in economics and business education?

Current reform initiatives are primarily oriented toward the needs of the economy. Additionally, by defining of useful knowledge at a social level as "the union of all the sets of individual

knowledge of the members of this society" (Mokyr, 2003:3), contemporary economic theory differs two main elements: „social“ and „useful“. Consequently, a central feature of the sociological approach should be directed towards definition of the most important basic goals of reforming the higher education system. Education as a public and a private good is both a subtle and a complex process of production. At the international level, the perception of the (higher) education functionality can result in improving their social role for a specific country on the global platform, indirectly giving the same benefits as at the national level (Krbec, 2002, 2004).

European as well as EU's accession countries are currently reorganizing their educational systems to enable individuals to learn continuously, acquiring that way new skills in the application of knowledge throughout their entire working times. Following the rationales of new higher education policies, HE institutions are constantly forced to change their traditional, passive role in transmitting knowledge, and use more competence-based methods of producing and applying knowledge. Namely, HE institutions should be encouraged and enabled to develop and pursue their own distinct internationalization profiles, based on choices that fit their strengths, particular characteristics, environment and their own steering models (e.g. more or less centralized, more or less competitive approaches) (EC, 2006).

The GBP is an international consulting project that allows students to earn credits and gain international experience. Students work on real-world projects whose success depends on their intellectual and practical application of key business concepts.

The GBP is experiential in nature. More than 20 years ago a number of scholars, such as Burnard (1989), Joplin (1981), and Kolb (1984), have already argued that experiential learning is superior to traditional methods. Experiential learning requires active participation; it is student-based; it allows students to build on subjective evaluations and perceptions; it is inductive and explorative.

After the historical influence of John Dewey's "learning by doing" philosophical approach, current experiential learning models were mostly developed in late 1980's. Experiential learning theory (further: ELT) defines learning as "the process whereby knowledge is created through the transformation of experience (Kolb, 1984:41). The ELT model portrays two dialectically related modes of grasping experience: concrete experience (CE) and abstract conceptualization (AC), and two dialectically related modes of transforming experience: reflective observation (RO) and active experimentation (AE). According to the original Kolb's four-stage learning cycle depicted in Figure 1, immediate or concrete experiences are the basis for observations and reflections. These reflections are 
assimilated and distilled into abstract concepts from which new implications for action can be drawn. These implications can be actively tested and serve as guides in creating new experiences (Kolb, Boyatzis and Mainemelis, 1999:3). The stage of Kolb's experiential learning cycle is sequential and mutually reinforcing no matter of which an "experience" is starting.

More recently, Kolb and Kolb (2008) describe the ELT as a useful framework to design and implement management education programs in higher education and management training and development. They analyzed the key concepts from ELT - the learning cycle, learning style, learning space, deep learning and development - can be used to examine management as a learning process at the level of the individual, the team and the organization.

\section{Figure 1.}

\section{Experiential Learning Cycle and its Implementation}

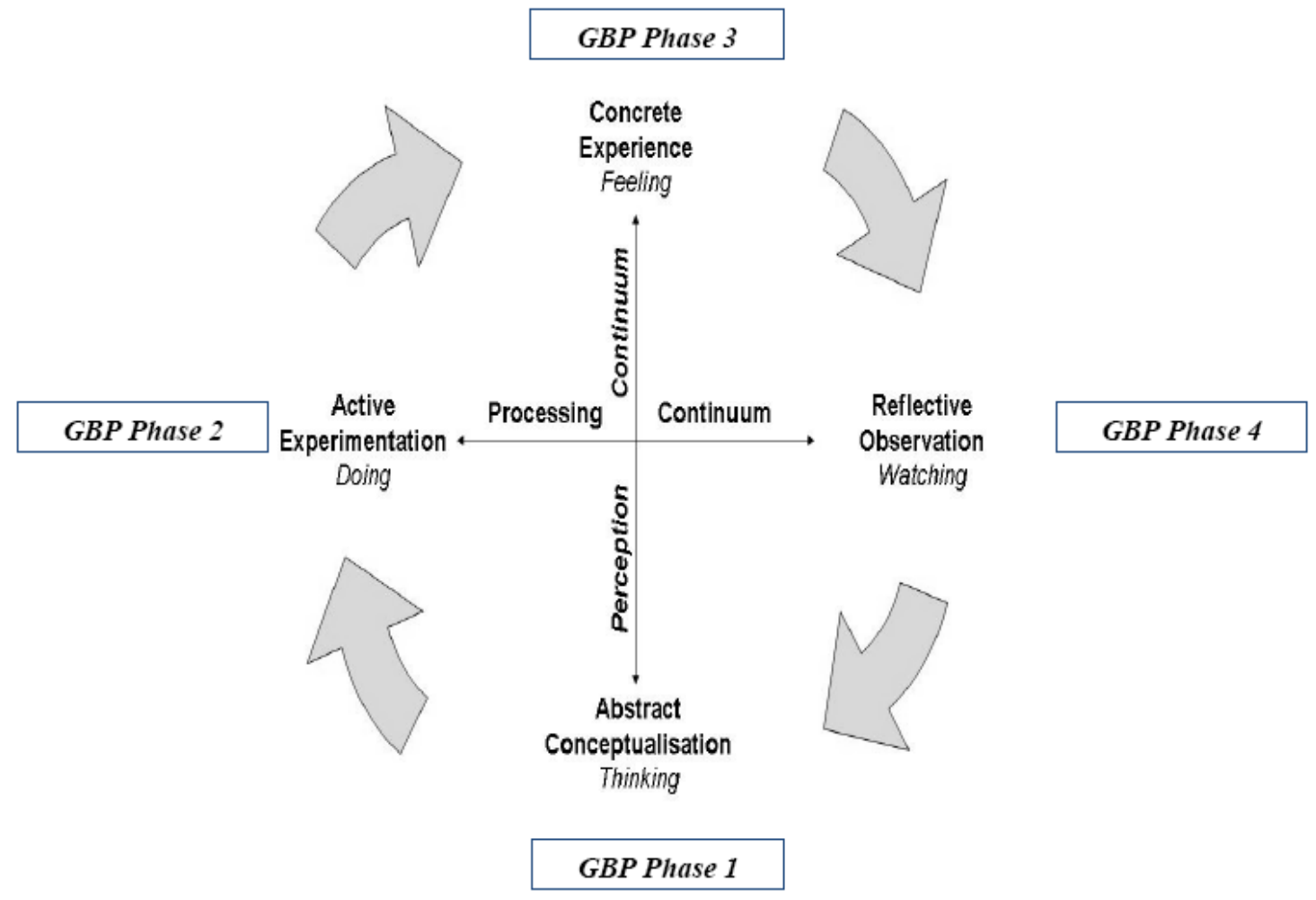

Teamwork is now prevalent in organizations, yet it has pitfalls such as social loafing, groupthink, overdependence on a dominant leader, overcommitment to goals, and diffusion of responsibility (Kayes, Kayes \& Kolb, 2005:330).

In terms of the GBP program's structure, the cycle is designed to foster learning capabilities of business students involved in a project (Figure 1). Upon completion of the simulation based on models and theories from past and present experiences (GBP Phase 1), the team has knowledge about the functions of teams in general (GBP Phase 2), experience about the functions of its team specifically (GBP Phase 3), and awareness of learning and progress through the learning cycle modes (GBP Phase 4). The students' team work experiences from previous projects positively influenced on learning capabilities of students currently participated in the project improving both management and business practices' usage by facilitating learning in the same time. 
Consequently, experiential learning assignments in business classes (as the GBP at international level) are more likely to:

* develop students' interpersonal and communication skills,

* lead to an understanding of course concepts,

* promote teamwork and team building,

* improve listening skills, and

* improve critical-thinking and problem-solving skills.

According to proponents of experiential learning, the expected net effect is that students become more interested and engaged, retain the information better and for longer periods, and learn how to apply otherwise elusive theoretical constructs.

\section{INTERNATIONALIZATION OF ECONOMICS \& BUSINESS EDUCATION}

Bilateral internationalism creates opportunities for exchange visits between students in different countries (McConnell, 2000; Alon \& McIntyre, 2004; Gilin \& Young, 2009). While the current practices are based mainly on access to programs offered by well-known universities, a true internationally-based program is much more adapted to local conditions and needs. Regardless of the importance that curriculum contents should have in an academic sense, international programs are justified mainly on the basis of their outcomes, which sometimes are quite varied.

A framework for considering outcomes needs to include impacts on students, impacts on schools, and impacts on the broader society. The most frequently cited reasons for education re-form programs have to do with impact on students, with the most common outcome measure being some form of assessment of students' skill or knowledge in the various curriculum areas. However, a variety of outcome measures beyond academic achievement have also been used to assess the impact of education policies.

Students' benefits. Learning cannot be forced, it can only be assisted. From the constructivist perspective, learning occurs by the individual learner interacting with knowledge rather than processed from information received from an external source. So the process comes about through individual involvement in the construction of meaning.

The benefits of team experiences for undergraduate students are well documented (for a concise review, see: Williams, Beard \& Rymer 1991). Students in teams learn not only content-specific skills, but also highly transferable skills related to communication, time management, and cooperative action (McCorkle et al., 1999). Experiential learning via incourse teams is clearly the modus operandi in most business school curricula. Although teams do present administrative and social hurdles in their exercise, those teams can provide very relevant, real-world experience to students.

However, the student's attitudes toward the project and subsequent involvement in the team are a function not just of the scope of the project and the relevance of the task; the team formation process itself has an appreciable effect on student attitudes in the team. Nicholson, Oliphant and Oliphant (2002) are not the first to suggest this link between team formation and team outcomes. Their analysis allows us to respectively examine how important are team formation methods. In order for students to reap the fullest potential of these team exercises, they need to be fully engaged in the experience - intellectually and socially involved in the team and its outcomes.

Investigating the overall satisfaction with the team formation, Nicholson, Oliphant and Oliphant also explored several other outcomes: the degree to which the method mimics "realworld" job selection processes, the likelihood that students would get along with team members using this process, whether or not the process created an interesting learning 
situation, whether the process demonstrates that the instructor cares about student learning on the task, and perceived fairness of team formation results.

Results of their study suggest very different patterns of student responses regarding perceived fairness and their satisfaction level. Students' self-selection (perhaps the most common team formation method) performed well in terms of overall satisfaction but did not perform as well on other outcomes except the ability to get along with team members. Nicholson and Oliphant's conclusion suggests that satisfaction is strongly affected by the rapport and interpersonal dynamics within the work project team.

Students' assessments of the quality and value of their school experience are an important, if seldom evaluated outcome indicator, if only because they say something about motivation, which is absolutely critical to all other outcomes. Life-chance indicators are also very important, since the most important purposes of schools often have to do with what happens to students after they leave the institution.

Impact on schools. A surprisingly large proportion of the research on reforms activities focus on the impacts on schools rather than students. One of the most frequently assessed aspects is program's impact on teachers' work and their attitudes towards their work. Outcomes related to work might include:

* hours, time in and out of the classroom;

*attention to individual students;

professional development activities, and

* skill levels or teaching practices.

International programs have been found to have different effects on administrators than on teachers, partly because governance changes have altered the work of administrators in important ways. However, the relevant measures for administrators are generally similar to those used for teachers.

Some reforms are intended to affect school programs. Curriculum changes or graduation requirements are obvious examples. Many reform programs have not given very much attention directly to teaching and learning practices per se, with the possible exception of efforts to extend the use of educational technologies.

However, improved teaching and learning practices are clearly central to the achievement of all school outcomes and so should be a key part of assessing any reform. Although changes in school organization such as diminution of authority are usually argued as means to achieve other more important ends, they could also be considered as outcomes in themselves.

Impact on society. In the past decade, higher education has become increasingly international as more as students choose to study abroad or enroll in foreign educational programs and institutions in their home country. According to various analyses (e.g. OECD, 2004; CHEMS, 2004 or CDESR, 2007), one of the most common reasons of this growth is the need to build a more educated work-force in the home country, particularly in emerging economies.

In their review on business international programs - as the GBP is too - Doh and Vachani (2004) pointed out that experiential exercises can be particularly effective in creating an appreciation of developments in global business and political economy, such as those associated with transformations underway in emerging markets.

Experiential exercises are currently accepted as effective tools for making students' learning and - more largely - learning organization more advanced. 


\section{EMERGING OF AN INTERNATIONAL COOPERATION'S PROGRAM 4.1. THE CASE OF GBP AT CRUMMER GRADUATE SCHOOL OF BUSINESS}

Nature. Rollins College is a private, liberal arts university in the United States. One of its academic units is the Crummer Graduate School of Business, which offers the Master of Business Administration (MBA) degree. The Crummer MBA programs offer two optional ways for students to obtain exposure to international business practices. The International Study Trip and the Global Business Practicums (GBP) are offered to provide hands-on international experience that will help students prosper in the global marketplace (Rollins MBA Brochure 2010). The International Study Trip is designed for large groups (30 or more students) and offers an opportunity to meet one-on-one with high-ranking executives of premier multinational corporations in different countries. The goal is to observe first-hand the effects of cultural influences on business. Students on the International Study Trip are required to write a paper describing their experiences and relating their observations to the core curriculum of the MBA program.

The GBP is designed much like a practicum in a medical school, where students work directly with patients and make their diagnoses under the supervision of a clinical physician. In a business environment, the GBP becomes an international consulting project that allows students to deal directly with managers of a host firm, observe business practices, and provide advice about solving a problem that the manager faces. Students work on real-world projects whose success depends on their intellectual and practical application of key business concepts.

Each GBP consulting project is unique and the deliverables are defined jointly by the company manager, the students, and the professor. For example, in 2002, Crummer MBA students worked on a project to help internationalize the operations of a small electronics manufacturer of capacitors from Upstate New York - Custom Electronics Incorporated (CEI) - in establishing additional business in Germany. The student group focused on Germany because sales have dropped to almost nothing in the country over the last couple of years. To achieve this purpose, specific objectives were developed prior to departure for Europe, which allowed the students to better understand the electronics market in Germany. Five MBA students and their professor traveled to Germany to investigate the situation, interview experts, meet with the distributor, examine alternative distributors, and explore other ways to market into Germany.

In 2008, Crummer students and UniPu students collaborated on a project to establish analytical tools for tracking sustainable tourism development for Croatian tourism associations (tourism offices at local and regional level). The GBP "Crummer "08" was designed to create the surveys that measure consumer and local satisfaction with tourism for Istria County according to the United Nations World Tourism Organization's core indicators for sustainable tourism development in tourism destinations. Seven Crummer students and a professor traveled to Pula, where they worked with six students and two assistant professors from UniPu. The group developed two surveys (one for visitors and one for locals) that provided valuable data that could be used by tourism officials and managers. It was one of the first efforts at collecting data relating to visitor satisfaction.

Learning objectives. A number of learning outcomes can be directly attributed to the GBPs as they relate to international business education.

First, students learned to interact and communicate in a cross-cultural international setting with top governmental officials and business constituents. Meetings include discussions with various officials and business people.

Second, the students developed intimate knowledge, both tacit and explicit, of a foreign market, namely Croatia. In structuring the report to the company, the students had to 
develop an understanding of the drivers of Pula's economy, and then write a summary of the Pula economy and culture in addition to analysis of the tourism market in Istria which was the primary goal of several analyses from 2002 to 2008 .

The third student outcome is learning how to work as a team on an international project. The total involvement in each others' lives, the day-in day-out interaction with oneanother, is a source of additional stress not encountered in a classroom setting, but it also brings awareness and education beyond what is obtained in the classroom. This immersion requires from the students and the supervising faculty a greater level of flexibility, patience and maturity.

Finally, students learn how to write a professional business report that is presentable to top managers in a real company.

The report writing stage begins prior to the international trip through background research and ends after several iterations are completed after students return and are able to digest the materials that were collected during the trip (see: Matulich, 2003.; Alon, 2004).

\subsection{GLOBAL BUSINESS PRACTICUM: EXPERIENCE FROM THE CROATIAN PERSPECTIVE}

From the Croatian perspective, the starting idea for creating a similar mutually benefit relationship was to design a short business education practicum. Under the project title "Collaborative Student and Faculty Experiential Exchanges", Global Business Practicum was designed to strengthen the relationship between the Faculty of Economics and Tourism (FET) "Dr. Mijo Mirkovic" University of Rijeka at Pula, Croatia and the Crummer Graduate School of Business, Rollins College, in Winter Park, Florida. The goal was accomplished in the first two years (2000-2002) beyond original expectations (the Fulbright Foundation grant was for two years). In each of the two years a group of Croatian students and faculty spent two weeks in Florida hosted by the Crummer School, and a group of Crummer students and faculty spent two weeks in Pula hosted by FET.

The relationship between the participating schools has been strengthened as a result of this program. From year 2000 to 2008 , a total of over 60 Croatian students and faculty visited the Crummer School to become familiar with its faculty, staff, and students, its methods of teaching, and its relationship with the local business community. In the same period, 57 Crummer students and faculty spent two weeks working closely on GBPs with students and faculty of Department of Economics and Tourism (OET UniPu) in Pula. In addition, four Crummer Faculty members were (one is now) Fulbright Fellows at FET/UniPu, a direct result of his introduction to the school as part of this program.

In 2008, the GBP "Crummer "08" under the title "Sustainable Tourism in Istria" was organized and realized as an original interactive contribution to the major UniPu Department of Tourism's strengths:

- as a part of mandatory class "Practicum" (P100) (Module: Tourism; ECTS: 3), the GBP was

- actively directed by the scientific research "Sustainable Tourism in Croatia: A Taste of Istria" (Scientific Project No. 303-0000000-2451, the Ministry of Science, Education and Sport Republic of Croatia).

The GBP 2008. The visits to Croatia by Crummer faculty and students were organized to satisfy the needs of Crummer students, all of whom are graduate students working toward their MBA degrees. A requirement of the program was that these students must have completed a minimum of one year of their graduate studies, and must enroll in a Crummer elective course (INT 604, Global Business Practicum). While in Pula, they must work on a 
project, the research and preparation for which are typically done in the semester prior to departure is scheduled. Upon arriving in Pula, the Crummer students are paired with Croatian students with whom they work. The projects on which the students work are designed to offer a valuable educational experience and to provide benefits for the Croatian community, which depends largely of foreign tourism.

At the end of the project, the Crummer students were required to prepare a written report on the project they completed, and they receive three hours of academic credit toward their MBA degree.

To expose the Crummer students to Croatian culture and way of life, they were housed with families of FET students, usually those assigned to work on the project. This enables the visitors to develop a close relationship with their hosts, and interact with them at meals and outings. In addition to working on the project, the program in Croatia includes a number of cultural and educational activities. The visitors take escorted tours of local businesses, visit points of interest, and have free time available with their hosts.

Crummer faculties who accompany the students to Pula are also active during their visits. They interact with $\mathrm{OET} / \mathrm{UniPu}$ professors and administrators, and because acquainted with the school and area, so that they can lead future groups of students to Croatia. They also participate in the development of UniPu, such as the planning of a future graduate program or joint research projects.

Croatian visit to Florida. The 2008 itinerary included attending several lectures at Rollins College, meetings and discussions with students, faculty, and administrators, and visits to businesses with which the Crummer School has a close relationship. Along with these activities, the visit was to emphasize the cultural development and understanding of the guests, which was accomplished by housing them in the homes of Rollins students, faculty, and friends, and allowing sufficient time with their hosts to become acquainted with the American way of life. As members of a school of tourism, the Croatian visitors were also introduced to some of the unique tourist attractions in Florida, which coincidentally are businesses with which the Crummer School has close relationships. Visits to many of these businesses resulted not only in behind-the-scenes tours of operations, but also in substantial amounts of in-kind financial support which was not anticipated in the original budget submitted with the grant proposal. Without exception, the Croatian visitors were enthusiastic about their visit, highly satisfied with its educational and cultural achievements, and delighted with their experiences.

\subsection{EVALUATION OF THE COLLABORATION}

The fundamental criterion was how well the program fulfills the educational mission of that constituent. At the student level the mission was to allow the student to develop skills in critical thinking, to think across disciplinary and national boundaries, and to apply principles learned in the classroom. The educational mission for faculty was to broaden the classroom environment beyond lecturing, to enhance teaching skills and to learn to teach in English. The institution's educational mission was to broaden and modernize its curriculum, to develop a degree of autonomy as allowed by the ministry, and to build a quality graduate program by attracting foreign and domestic students. The government through the Ministry of Science was modernizing the higher education system in Croatia in an effort to improve the quality of education. It also wanted to encourage alternative pedagogical approaches, disseminate the use of technology and empower local institutions to be creative within the general educational policy of the government. 
One measure of the collaboration's success was whether each of the parties uses what it learns. Students developed a skill set that they didn't have before, which will enable them to become better managers. Faculty learned new pedagogy that they can use in the classroom. FET could use the collaboration as a recruiting tool in attracting students and faculty. The collaboration benefited the local economy because the results of the projects are implemented by the tourism industry. The government benefited from a paradigm that can be replicated at other universities.

Cost was an important consideration because the goal is to develop a program that couldn't be generalized throughout the curriculum. If the program has been provided educational benefits that justify its costs, it might be possible to require such experience.

\section{DISCUSSION}

1. For Crummer Graduate School of Business's students, the international business consulting trip is a high-level preparatory experiential class that requires a high level of coordination and preparation by the students and faculty alike. When comparing the experiences' level between Crummer MBA students and the OET UniPu undergraduates, it is probably more appropriate for an MBA program than an undergraduate program. Even within an MBA program, it is more appropriate for students who have some training in international business and who have a certain level of maturity and business experience. In both cases, an application process is highly recommended and the team makeup should be examined in detail prior to departure and/or to collaborate in the host institution.

2. The Practicum counts as 3 credits (both 3 USA/MBA credits and 3 ECTS) and students receive a grade at the end. The consulting project is a semester long project, out of which one week is used for field research, usually during the mid-semester break. For Crummer MBA it is an elective international business course, and the school runs these consulting projects twice a year. According to the licenced adacemic programs the OET UniPU is offering, Practicum class it is a mandatory undergraduate (P100) and/or graduate (P200) course performing each academic year.

3. There are also differences in the selection procedure between institutions. Crummer students are chosen by examining their academic and professional background. Oftentimes, these students are identified by the professor while they are taking his/her class. This way, the professor can better assess their academic qualifications and interpersonal skills. About five students participate in each consulting project. Most students that participate in the consulting project have some work experience, but students with no work experience that are in the second year of their MBA are also allowed to participate. The OET UniPu undergraduate and graduate students actively participate at chosen activities leading by their professor and faculties (mandatory class), while - because of the academic year project requirements - some of them are chosen to participate in particular project according to their knowledge, affiliation, and overall excellence (team-working readiness, communication skills, and sufficient knowledge of Business English).

4. The learning outcomes from an international business practicum complement the traditional class setting and give the students perspectives which are difficult to bring into the classroom. The students value these experiences because they provide an element of realism which is difficult to emulate in the classroom and allow the students to synthesize and apply the courses they have already taken. Given the positive outcomes that are possible, MBA programs are advised to develop experiential 
international business education curriculum to their students in order to prepare them for managerial positions in the global business environment of the future.

\section{CONCLUDING REMARKS}

Work-directed team projects such as the Global Business Practicum, shaped and evaluated as an international economics and/or business education program for students with different educational experiences and possibilities to learn from businesses, promote mutual understanding and (knowledge) competence. Working on diverse project themes, students are forced gradually to experience business practices in different social contexts.

Regardless of whether a broader higher educational reform is at work (as it is in Croatia presently) or it concerns the reconstruction of a specific part of educational process, organizational and also technological solutions yet applied in schools/faculties are able to influence qualitative shifts in "producing" education. The introduction and the implementation of mutually beneficial programs certainly contribute to a different, reformoriented type of learning.

\section{REFERENCES}

Alon, I. (2004). The Global Practicum as an Innovative Pedagogical Tool for Learning International Management. Working Paper. Crummer School of Business at Rollins College, December 2004

Alon, I. \& McIntyre, J.R. (Eds.) (2004). Business Education and Emerging Market Economies. Perspectives and Best Practices. Boston: Kluwer Academic Publishers.

Beranek, S. (2003). Mutually Beneficial Learning Experience Helps Crummer and Croatian Students. Crummer Connection. Crummer School of Business at Rollins College, Winter 2003

Burnard, P. (1989). Teaching Interpersonal Skills: A Handbook of Experiential Learning for Health Professionals. London: Chapman \& Hall.

Charon Wauters, A. (2006). Internalization in European Higher Education. Trends and Tools. Presentation. IAU International Conference Internationalization of HE New Directions, New Challenges. Beijing: October 12-15, 2006

CHEMS et al. (2004). Higher Education Institutions' Reponses to Europeanisation, Internationalisation and Globalisation. New Perspectives for Learning - Briefing Paper No. 60 (F5). Retrieved from: http://www.pjb.co.uk/npl/bp60.pdf

CDESR -BU(2007). The University between Humanism and Market: Redefining its values and functions for the 21 st century. Report and Conclusions of the Conference. Item 7. Council of Europe Conference New Challenges to Higher Education Managing the Complexities of a Globalised Society. Strasbourg: Steering Committee for Higher Education and Research (CDESR) Bureau, November 20-21, 2007. Retrieved from Retrieved from : http://www.coe.int/t/dg4/highereducation/UnivHumanismMarket/CDESRBU_2007_17_E N.pdf

Currie, D.M.; Krbec, D.\& Higgins, J. (2005). Creating a Quality Assurance System for Croatian Higher Education. Higher Education in Europe - Thematic issue "The Bologna Process: Retrospect and Prospects", XXX (1), 53-66

Currie, D., Krbec, D.\& Matulich, S. (2004). The Use of Global Work-Directed Teams in Promoting International Competence: The Case of Croatia. In: Alon, I.\& McIntyre, J.R. (Eds.) Business Education and Emerging Market Economies. Perspectives and Best Practices. Boston: Kluwer Academic Publishers, pp. 251-266 
Doh, J.P.\&Vachani S. (2004). Using Experiential Exercises to Underscore the Challenges and Opportunities of Emerging Markets. In: Alon, I.\& McIntyre, J.R. (Eds.) Business Education and Emerging Market Economies. Perspectives and Best Practices. Boston: Kluwer Academic Publishers, pp. 217-234

EC (2006). Building our common Future: Policy challenges and Budgetary means of the Enlarged Union 2007-2013. Decision No. 1720/2006/EC of the European Parliament and of the Council, Official Journal of the European Union, November 24, 2006

European Science Foundation, ESF (2008). Higher Education Looking Forward: An Agenda for Future Research. Strasbourg cedex: ESF.

Exeter, D. J. (2001). Learning in the Outdoors. London: Outward Bound.

Gillin, B. \& Young, T. (2009). Educational Benefits of International Experiential Learning in an MSW Program. International Social Work , 52 (1): 36-47

Johnson, J.P. (2004). Experiential Learning in Emerging Markets: Leveraging the Foreign Experience. In: Alon, I. \& McIntyre, J.R. (Eds.) Business Education and Emerging Market Economies. Perspectives and Best Practices. Boston: Kluwer Academic Publishers, pp. 235-249

Joplin, L. (1981). On Defining Experiential Education. Journal of Experiential Education, 4 (1): $17-20$

Kayes, A.; Kayes, Ch.\& Kolb, D. (2005). Experiential Learning in Teams. Simulation and Gaming, 36 (3): 330-354

Kolb, A.\& Kolb. D. (2008). Experiential Learning Theory: A Dynamic, Holistic Approach to Management Learning, Education and Development. In: Armstrong, S. J. \& Fukami, C. (Eds.). Handbook of Management Learning, Education and Development. London: Sage Publications.

Kolb, D.A., Boyatzis, R. \& Mainemelis, Ch. (1999). Experiential Learning Theory: Previous Research and New Directions. Cleveland, OH: Weatherhead School of Management. Retrieved from : http://www.learningfromexperience.com/images/uploads/experientiallearning-theory.pdf

Kolb, D.A.(1984). Experiential Learning: Experience as the Source of Learning and Development. Englewood Cliffs, NJ: Prentice Hall.

Krbec, D. (2004). "Europeanization" of Education: Challenges for Accession Countries. In: Svarc, J.; Laznjak, J.; Sporer, Z. \& Polsek, D. (Eds.): Transition Countries in the Knowledge Society: Socioeconomic Analysis. Zagreb: Institute of Social Research, pp. 375-391

Krbec, D. (2002). Shaping New Paradigms in the Higher Education Development: Dilemmas for Transitional Countries. Presentation. 2002 Informing Science +It Education (InSITE "Where Parallels Intersect") Conference. Cork: University of Cork, June 19-22, 2002

Matulich, S. (2003). Collaborative Student and Faculty Experiential Exchanges, AIA Final Report (10-01-2000 - 10-01-2002). Washington, DC: Fulbright Foundation.

McConnell, D. (2000). Importing Diversity: Inside Japan's JET Program. Berkeley: University of California Press.

McCorkle, D., Reardon, J., Alexander, J.F., Kling, N.D., Harris, R.C.\& Vishwanathan, I. (1999). Undergraduate Marketing Students, Group Projects, and Teamwork: the Good, the Bad, and the Ugly? Journal of Marketing Education, 21(2): 106-117

Mokyr, J. (2003). The Knowledge Society: Theoretical and Historical Underpinnings. Paper presented the Ad Hoc Expert Group on Knowledge Systems, Sept 4-5, 2003. New York: United Nations (.pdf)

Nicholson, C.Y.; Oliphant, G.C.\& Oliphant, R.J. (2002). Project Team Formation Processes: Student Attitudes and Experiences in Nine Alternative Methods, Journal of the Academy of 
Business Education. Proceedings 2002, Vol. 3. Retrieved from

http://www.abe.villanova.edu/proc2002/proceed2002.html

OECD (2004). Internationalization of Higher Education. OECD Observer, August 2004.

Rollins MBA Brochure (2010). Brand Guidelines. Retrieved from

http://issuu.com/rollinscollege/docs/brand guide

Williams, D. L., Beard, J.D.\& Rymer, J. (1991). Team Projects: Achieving Their Full

Potential. Journal of Marketing Education, 13(2): 45-53

\title{
PREDNOSTI ISKUSTVENOG UČENJA U RAZVOJU MEĐUNARODNIH STUDIJSKIH PROGRAMA EKONOMIJE I POSLOVNE EKONOMIJE
}

\begin{abstract}
Sažetak
Procesi internacionalizacije $u$ visokom obrazovanju moraju poštivati jedinstvenost pojedinih društava $i$ kultura, te - u okolnostima sveopće globalizacije - moraju poticati razumijevanje $i$ suradnju u okvirima međunarodne akademske suradnje. U tom je kontekstu moguće razumijevanje međunarodne dimenzije visokog obrazovanja kao perspektive, aktivnosti ili programa koji uključuju interkulturalni pristup temeljnim funkcijama sveučilišta.

Global Business Practicum na Rollins College-u i suradnja između Rollins-a i Sveučilišta Jurja Dobrile, Odjela za ekonomiju i turizam "Dr. Mijo Mirković” u Puli pružaju brojne poučne primjere o obrazovanju studenata ekonomije i poslovne ekonomije uz sudjelovanje u poslovnim projektima, te mogućnostima evaluacije međunarodne suradnje kroz sustav ECTS-a i - jednako tako sustav vrednovanja koji se primjenjuje u SAD-u.
\end{abstract}

Ključne riječi: iskustveno učenje, iskustva studenata, ekonomsko i poslovno obrazovanje, praktikum, Hrvatska 